\title{
Antibody-mediated oral delivery of therapeutic DNA for type 2 diabetes mellitus
}

Seungbin Cha', Sun Hwa Lee ${ }^{2}$, Sung Hun Kang ${ }^{2}$, Mohammad Nazmul Hasan², Young Jun Kim*, Sungpil Cho ${ }^{4^{*}}$ and Yong-Kyu Lee $2,3,4^{*}$

\begin{abstract}
Background: Diabetes mellitus (DM) is a chronic progressive metabolic disease that involves uncontrolled elevation of blood glucose levels. Among various therapeutic approaches, GLP-1 prevents type 2 diabetes mellitus (T2DM) patients from experiencing hyperglycemic episodes. However, the short half-life $(<5 \mathrm{~min})$ and rapid clearance of GLP-1 often limits its therapeutic use. Here, we developed an oral GLP-1 gene delivery system to achieve an extended antidiabetic effect.

Methods: Human lgG1 (hlgG1)-Fc-Arg/pDNA complexes were prepared by an electrostatic complexation of the expression plasmid with various ratios of the positively modified Fc fragments of an antibody (hlgG1-Fc-Arg) having a targeting ability to FcRn receptor. The shape and size of the complexes were examined by atomic force and field emission electron microscope. The stability of the complexes was tested in simulated gastrointestinal $\mathrm{pH}$ and physiological serum condition. Cellular uptake, transport, and toxicity of the complexes were tested in the Caco-2 cells. Biodistribution and antidiabetic effect of the complexes were observed in either Balb/c mice or Lep $\mathrm{db}_{\mathrm{db}} \mathrm{db}$ mice.

Results: A 50/1 ratio of the hlgG1-Fc-Arg/pDNA produced a complex structure having approximately $40 \sim 60 \mathrm{~nm}$ size and also demonstrated protection of pDNA in the complex from the physiological pH and serum conditions. Cellular uptake and transport of the complex were demonstrated in Caco-2 cells having FcRn receptor expression and forming the monolayer-polarized structure. The cellular toxicity of both delivery vehicle and the complex revealed their minimal toxicity comparable with nontoxicity of a commercial transfection reagent. Biodistribution of the complex showed the detectable distribution of the complex in the most parts of gastrointestinal tract due to ubiquitous expression of the FcRn receptors. An in vivo type 2 diabetes treatment study of oral administration of hlgG1-Fc-9Arg/pGLP-1 complexes showed absorption and expression in Gl tract of either Balb/c mice or Lep $\mathrm{db} / \mathrm{db}$ mice.

Conclusion: In this study, we developed an oral GLP-1 gene delivery system on the platform of cationic hlgG1-Fc9 Arg. Prolonged t1/2, less immunoactivity, and better bioactivities of hlgG-Fc-9Arg/pGLP-1 complexes appeared to be a promising approach to achieve potent treatment of type 2 diabetes treatment.
\end{abstract}

Keywords: Type 2 diabetes, GLP-1, Oral gene delivery, FcRn

\footnotetext{
* Correspondence: ykim@kku.ac.kr; sungpilcho74@ut.ac.kr; leeyk@ut.ac.kr

'Department of Biomedical Chemistry, Konkuk University, Chungju 27478,

Republic of Korea

${ }^{4} 4 \mathrm{D}$ Biomaterials Center, Korea National University of Transportation,

Jeungpyeong 27909, Republic of Korea

${ }^{2}$ KB-Biomed, Chungju 27469, Republic of Korea

Full list of author information is available at the end of the article
}

(c) The Author(s). 2018 Open Access This article is distributed under the terms of the Creative Commons Attribution 4.0 International License (http://creativecommons.org/licenses/by/4.0/), which permits unrestricted use, distribution, and reproduction in any medium, provided you give appropriate credit to the original author(s) and the source, provide a link to the Creative Commons license, and indicate if changes were made. The Creative Commons Public Domain Dedication waiver (http://creativecommons.org/publicdomain/zero/1.0/) applies to the data made available in this article, unless otherwise stated. 


\section{Background}

Diabetes mellitus (DM), commonly known as diabetes, is a chronic, progressive metabolic disease of uncontrolled elevation of blood glucose levels [1]. According to a 2016 WHO report, the global burden of diabetes in 2014 was 422 million people, a prevalence of $8.5 \%$ among the total adult population [1]. Without proper management, complications including vision loss, kidney failure, cardiovascular disease, and lower limb amputation lead to premature death [1]. Type I diabetes (T1DM), characterized by the need for daily administration of insulin, results from autoimmune destruction of insulin-producing pancreatic $\beta$-cells $[2,3]$. However, type II diabetes (T2DM), accounting for the majority of diabetes cases around the world, stems from either insulin resistance or insufficient insulin production $[3,4]$. Even though there have been advances in the understanding of the pathogenesis and control of both forms of diabetes, therapeutic methods including insulin injection remain unsatisfactory [3]. Injectable insulin is not physiologically controlled and generates patient non-compliance, resulting in suboptimal control and ensuing diabetic complications. The glucose-lowing agents offered as alternatives to insulin injection include amylin analogs, sodium/glucose cotransporter-2 (SGLT-2) inhibitors and dipeptidyl peptidase IV (DPP-IV) inhibitors [5]. Hypoglycemia from these anti-diabetic agents is the significant adverse effect [5]. Among these glucose-lowering agents, glucagon-like peptide-1 (GLP-1) is a natural gut-derived small peptide hormone produced from intestinal L-cells after a meal [6]. GLP-1 has numerous roles as a physiological regulator of lowering hyperglycemic condition, and inhibition of gastric emptying and food intake [6]. The demonstrated antidiabetic effect of the GLP-1 has led to approval of the GLP-1 receptor agonist such as exendin-4 (Byetta $\left.{ }^{\oplus}\right)$ that is strictly glucose-dependent, reducing the risk of hypoglycemia [5, 6]. While GLP-1 has its superior insulinotropic effect, use of GLP-1 for diabetes remains problematic because of its short plasma half-life (approximately $5 \mathrm{~min}$ ) and rapid metabolic clearance [7-13].

Therapeutic gene delivery systems with various gene carriers including nonviral vectors are potential solutions to the limitations of current diabetic treatments. Nonviral gene delivery is achieved by either nano-size gene complexation or adsorption of the gene to nanoparticles through an interaction between negatively charged DNA and nonviral cationic carriers such as polymers, lipids and inorganic materials [8]. Recent advances and consideration of the prospects for their application provide better methods of diabetic treatment, primarily for the prevention and cure of T2DM. However, direct intravenous injection of these systems limited further application of gene delivery regarding serum stability, immunogenicity, low transfection efficiency and high costs, encouraging researchers to focus on alternative systems [8, 14-20].

Oral gene delivery is an attractive alternative to parenteral routes, offering several apparent advantages. First, ease of administration leads to improved patient convenience and compliance. Second, limited biodistribution by transfecting genes almost exclusively to intestinal epithelial cells is advantageous regarding safety concerns [21]. Furthermore, efficient oral gene delivery systems could lead to the expression and secretion of therapeutic proteins into the systemic circulation. Although proof of concept for oral gene therapy has already been provided, nonviral gene delivery through the gastrointestinal (GI) tract has rarely been investigated due to a reduced chance of protein expression by low gene transfection efficiency. Additionally, the GI tract itself provides barriers, leading to a reduction in the number of genes reaching a target in intact form. Most notably these barriers are low gastric $\mathrm{pH}$, the mucus gel layer and enzymatic degradation caused by intestinal nucleases [21, 22].

Neonatal Fc receptor (FcRn) plays a role in transporting human IgG1(hIgG1) in breast milk from mother to offspring across the polarized intestinal layer. hIgG1 has a prolonged circulation time, with a half-life $\left(t_{1 / 2}\right)$ of 21 days compared with the $t_{1 / 2}$ of other Ig classes. The complexation of hIgG1 to FcRn led to the enhancement of the $t_{1 / 2}$ of hIgG1 and facilitated cellular transport across the intestinal layer [23-25]. The Fc portion of IgG binds with high affinity to FcRn in acidic $\mathrm{pH}(<6.5)$ but not at a physiological $\mathrm{pH}$ (7.4). In the gut of neonatal rodents, after passing through the stomach, the slightly acidic stomach content containing maternal IgG pass into the duodenum. IgG binds to FcRn on the apical surface of epithelial cells. Following transcytosis process, FcRn releases bound IgG into the underlying extracellular space which is at physiological pH (7.4). In human, the syncytiotrophoblast internalizes fluid containing maternal IgG into endosomes, and it is gradually acidified, allowing IgG to bind tightly to FcRn present in the chamber. Then, the vesicle fuses with the membrane on the fetal side of the syncytiotrophoblast, where the dissociation of IgG happens in physiological $\mathrm{pH}$ [24]. The Fc fragment has been concerned with the prolonged survival of hIgG1 because Fc fragments had a similar $t_{1 / 2}$ to that of intact hIgG1 and much longer survival than did Fab fragments [24]. This prolongation was interpreted by the existence of an Fc receptor preserving hIgG1 Fc fragments from normal lysosomal degradation [26, 27]. Discovery of the interaction of Fc of hIgG1 with FcRn provided an insight into the development of a carrier system to overcome GI barriers in oral gene delivery [23-25].

In this study, we developed an oral $\mathrm{p} \beta$-sp-GLP-1 gene delivery system on the platform of cationic hIgG1-Fc-9Arg. Bioactivity of this oral gene delivery 
system demonstrated the expression of a potential long-acting GLP-1 in T2DM db/db mice. Prolonged $t_{1 / 2}$, less immunoactivity, and better bioactivities of hIgG-Fc-9Arg/p $\beta$-sp-GLP-1 complexes suggested advantages over direct insulin injection or administration of chemical drugs for T2DM treatment.

\section{Methods}

\section{Materials}

Fluorescein isothiocyanate (FITC), bobo-3 iodide (570/ 602), and Lipofectamine ${ }^{\mathrm{Tw}}$ Plus were purchased from Thermo Fisher Scientific (Waltham, MA, USA). Exfection $^{\text {Tx }}$ LE Mini was purchased from GeneAll Biotechnology (Seoul, Korea). Minimum Essential Medium (MEM), RPMI 1640 and Dulbecco's Modified Eagle's Medium (DMEM), Dulbecco's Phosphate Buffered Saline (PBS), and trypsin were purchased from Sigma Aldrich (Taufkirchen, Germany), and fetal bovine serum (FBS) was purchased from EMD Millipore (US Origin). Caco-2 and HT-29 (human epithelial colorectal adenocarcinoma cell lines), HEK-293 (human embryonic kidney cell line), and HeLa (human cervical carcinoma cell line) were purchased from the Korean Cell Line Bank (KCLB, Korea). The GLP-1 ELA kit was purchased from Sigma-Aldrich (St. Louis, MO, USA). Ultrasensitive mouse insulin ELISA kit was purchased from Morinaga (Yokohama, Japan). A pAcGFP-N1 expression plasmid was kindly provided by Dr. Young Jun Kim (Konkuk University, Chungju, Korea). A $\mathrm{p} \beta$-sp-GLP-1 expression vector was obtained from Dr. Minhyung Lee (Hanyang University, Seoul, Korea).

\section{Animals}

Balb/c mice (5-7 weeks old) and Lep $_{\mathrm{db} / \mathrm{db}}$ mice (male, 7-9 weeks old) were purchased from Daehan Bio Link, Inc. (Chungbuk, Korea). All mice were maintained in sterile, autoclaved cages, 3 per cage, on a standard chow diet. All animal experiments followed the guidelines established by Chonnam University Institutional Animal Care Use Committee and other proper approvals were obtained before the study.

\section{Preparation of hlgG1-Fc-9Arg}

hIgG1-Fc-9Arg protein was prepared by a transient cell-based protein expression system. Briefly, the C-terminus of a hIgG1-Fc expression plasmid (Korea Research Institute of Bioscience \& Biotechnology, South Korea) was extended with nine-arginine (9 Arg) sequences by PCR. The extension of 9 Arg from hIgG1-Fc was confirmed by both PCR amplification and DNA sequencing [28-31]. The hIgG1-Fc-9Arg expression plasmid was further introduced into Expi293F cells using ExpiFectamine ${ }^{\text {Tx }}$ 293 transfection reagent according to manufacturer's instructions. At 6-7 days of cell culture after transfection, the cleared supernatants were harvested by centrifugation at $8000 \mathrm{rpm}$ for $15 \mathrm{~min}$ and microfiltration with $0.22 \mu \mathrm{m}$ microfilter. A-HiTrap Mabselect SuRe column (GE Lifesciences, Buckinghamshire, England) was used to separate the hIgG1-Fc-9Arg protein from the supernatants. The hIgG1-Fc-9Arg protein eluted from the column was neutralized with $1 \mathrm{M}$ Tris ( $\mathrm{pH}$ 8.5). After buffer exchange of the neutralized eluent with PBS containing 5\% trehalose (pH 7.4), the hIgG1-Fc-9Arg protein solution was concentrated with ultracentrifugal filter $(3 \mathrm{kDa}$ Amicon Ultra $2 \mathrm{~mL}$ centrifugal filter, Millipore-Sigma, Burlington, MA, USA). The size of hIgG1-Fc-9Arg was confirmed by both SDS-PAGE and PAGE.

\section{Complexation of hlgG1-Fc-9Arg with pAcGFP-N1}

Various weight ratios of hIgG1-Fc-9Arg /pAcGFP-N1 complexes were prepared in microcentrifuge tubes by addition of pAcGFP-N1 $(1 \mu \mathrm{g} / \mu \mathrm{l})$ into hIgG1-Fc-9Arg $(9 \mu \mathrm{g} / \mu \mathrm{l})$ following adjustment of final volume by PBS (pH 7.4) (Additional file 2). After stabilization of the complex with 30-min incubation at room temperature, the complex was applied to a DNA retardation assay to ensure DNA-complexation by electrophoresis on $1 \%$ agarose gels under tris-acetate-EDTA (TAE) buffer at $100 \mathrm{~V}$ for $30 \mathrm{~min}$.

\section{Characterization of hlgG1-Fc-9Arg/ pAcGFP-N1 complex}

The surface properties of hIgG1-Fc-9Arg/pAcGFP-N1 complexes $(20 / 1,50 / 1,100 / 1, w / w)$ were analyzed by an atomic force microscope (AFM, Multimode-N3-AM, Bruker crop., Germany) in Tapping Mode ${ }^{\mathrm{Tw}}$. The shape and size of an hIgG1-Fc-9Arg/ pAcGFP-N1 complex $(50 / 1, w / w)$ were observed by a Field Emission Transmission Electron Microscope (FE-TEM, JEM-2100F, JEOL Ltd., Japan) at $20 \mathrm{kV}$ in high vacuum mode [30]. The samples were prepared by spreading 1000 -fold diluted hIgG1-Fc-9Arg/pAcGFP-N1 complexes on a copper grid and drying the samples.

pH and serum stability of hlgG1-Fc-9Arg/pAcGFP-N1 complex Orally administered biological compounds need to be stable without loss of their activity from $\mathrm{pH}$-fluctuations during gastrointestinal transit and from serum instability during systemic circulation. To estimate the stability of hIgG1-FC-9Arg during gastrointestinal transit, hIgG1-FC-9Arg was incubated for 0,30 , and $60 \mathrm{~min}$ at various $\mathrm{pH}$ conditions. SDS-PAGE was performed to check the stability of hIgG1-FC-9Arg after incubation. The stability of hIgG1-Fc-9Arg/pAcGFP-N1 $(50 / 1, w / w)$ complexes were also assessed by $1 \%$ agarose gel electrophoresis with samples that were prepared after incubation at various times at $\mathrm{pH} 2$, the average $\mathrm{pH}$ of the stomach.

Various ratios of the complex were incubated for up to $24 \mathrm{~h}$ with $10 \%$ fetal bovine serum (FBS) at $37{ }^{\circ} \mathrm{C}$ to assess serum stability of the complexes. After incubation, samples were treated with EDTA to stop the further 
enzymatic reaction and were subjected to $1 \%$ agarose gel electrophoresis.

Samples were treated with 1\% SDS to release plasmid DNA to estimate either $\mathrm{pH}$ or serum effect of the pAcGFP-N1 plasmid in the complex. Noncomplexed pAcGFP-N1 plasmid, a naked pDNA, was used as a comparison with the samples.

\section{FcRn-mediated cellular uptake of hlgG1-Fc-9Arg/pDNA complex}

The expression of FcRn was measured by immunoblotting the cell extracts obtained from human epithelial colorectal adenocarcinoma cells (Caco-2, HT-29), human embryonic kidney cells (HEK 293), and human cervical carcinoma cells (HeLa). HEK293-FcRn cell extracts played the role of positive FcRn expression controls to ensure the expression of FcRN in the experimental samples.

Ten $\mu$ g FITC-hIG1-Fc-9Arg conjugate was added to the HeLa, HEK293, and Caco2 cells for $1 \mathrm{~h}$ to check whether the FcRn cell surface receptor played a role in cellular uptake of the hIgG1-Fc-9Arg complex. The confocal microscopic analysis confirmed the green fluorescence emitted from FITC in the conjugate. In addition to FITC conjugates, 20:1, 50:1 and 100:1 ratio of the hIgG1-FC-9Arg/pAcGFP-N1 complex was added to the Caco- 2 cells for $48 \mathrm{~h}$, and GFP expression was monitored. CaCo-2 cells transfected with pAcGFP-N1 using lipofectamine were transfection controls to compare GFP expression from the experimental samples treated with the complex.

\section{Cellular toxicity of hlgG1-Fc-9Arg/pDNA complex}

To determine the cellular toxicity of the complex, an MTT-based cell viability assay was performed in Caco-2 cells according to the manufacturer's instructions. Caco-2 cells that were plated in the 96-well plates at 0.1 million cells per well at $24 \mathrm{~h}$ before the treatment were treated with the complex for $24 \mathrm{~h}$. After treatment, culture media was replaced with MTT solution consisting of $20 \mu \mathrm{l}$ MTT $(5 \mathrm{mg} / \mathrm{ml}, w / v)$ solution and $180 \mu \mathrm{l} \mathrm{media}$ and were further incubated for $30 \mathrm{~min}$ to an hour at $37{ }^{\circ} \mathrm{C}$ to observe insoluble formazan crystals in the cells. After finishing MTT treatment, DMSO treatment completely solubilized the formazan crystals in the cells. The absorbance at $570 \mathrm{~nm}$ of the solution proportionally increased with the numbers of viable cells. The percentage cell viability was described by the following equation:

$$
\% \text { viable cells }=\frac{\left(a b s_{\text {sample }}-a b s_{\text {blank }}\right)}{\left(a b s_{\text {control }}-a b s_{\text {blank }}\right)} \times 100
$$

$a b s_{\text {sample: }}$ absorbance of the sample with a treatment. $a b s_{\text {control }}$ : absorbance of the sample without treatment. abs blank: $_{\text {: }}$ absorbance of DMSO.
Cellular transport of hlgG1-Fc-9Arg/pDNA complex across the Caco-2 cell monolayer

A transwell permeability assay with monolayered Caco-2 cells simulated cellular transport of materials from the apical region to basolateral region of the gastrointestinal tract [32-34]. Briefly, the complex prepared from various ratios of hIgG1-Fc-9Arg and bobo-3 pDNA was applied to the apical site of the Caco-2 cells monolayered on a transwell system (Corning ${ }^{\circ}$ Transwell $^{\circ}$ polyester membrane pore size $0.4 \mu \mathrm{m}$, diameter $12 \mathrm{~mm}$ cell culture inserts, Millipore). The determination of apical-to-basolateral translocation of the complex was the measurement of fluorescence intensity emitted from the bobo- 3 pDNA complex in the basolateral medium (HBSS, pH 7.4).

\section{Endosomal trafficking of hlgG1-Fc-9Arg complex}

The experimental cells were the Caco- 2 cell line for treatment of $10 \mu \mathrm{g}$ FITC-hIgG1-Fc-9Arg complex for either $30 \mathrm{~min}$ or $4 \mathrm{~h}$. The additional 10 -min treatment of Caco-2 cells with lysotracker led to staining late endosomes and lysosomes in the cells. The fluorescent images obtained from FITC and lysotracker in the cells indicated the endosomal locations of the complex.

Intracellular fluorescence emitted from the various ratios of hIgG1-Fc-9Arg/bobo-3 pDNA complex demonstrated the endosomal fate of the complexes. A positive control to monitor endosomal trafficking of the complexes was the cells treated with a commercial transfection reagent, Lipofectamine.

\section{Biodistribution of a FITC- hIGg1-Fc-9Arg complex}

$\mathrm{Balb} / \mathrm{c}$ mice ( $n=3$, male, 5-7 weeks) were the experimental animal given the oral administration of $10 \mu \mathrm{g}$ FITC-hIgG1-Fc-9Arg complex. At either 1 or $3 \mathrm{~h}$ after oral feeding, various parts of organs from the mice were harvested and imaged to observe biodistribution of the complex by using a Kodak Digital Science ${ }^{\text {Tx }}$ Image Station 440CF (IS440CF) system. After imaging, the organs were further processed into a solution obtained from grinding the liquid nitrogen-frozen organ with mortar and pestle. Quantification of the organ distribution of the complex was performed by measurement of the fluorescence intensity emitted from FITC in the complex by microplate spectrometry.

\section{Antidiabetic effect of a hlgG1-Fc-9Arg/pGLP-1 complex}

Lep $_{\mathrm{db} / \mathrm{db}}(n=4$, male, 7 weeks $)$ and Balb/c $(n=3$, male, 5-7 weeks) mice received oral administration of hIgG1-Fc-9Arg/ p $\beta$-sp-GLP-1 complexes (50/1). The complex contained $20 \mu \mathrm{g}$ of $\mathrm{p} \beta$-sp-GLP-1 and was given to the mice on $0,7,14,21,35,44$ days. Control mice received PBS by oral route following the same dosing schedule. At every oral dosing time, mice underwent 
measurement of glucose levels and body weight with a glucose meter and weight balance. Experimental mice supplied their blood from their abdominal-inferior vena cava after $8 \mathrm{~h}$ fasting for further processing of the serum by centrifugation. The performance of EIA (Sigma-Aldrich) and ELISA (Morinaga) with the serum provided information regarding the level of GLP-1 and insulin. HE histology analysis estimated intestinal tissue toxicity after oral administration of the complex to the mice.

\section{Statistical analysis}

All applicable data are expressed as a mean \pm standard deviation unless otherwise noted. Statistical analysis was performed with Prism software (version 7.04; GraphPad Software, La Jolla, CA, USA). Significance was set at $p<0.05$.

\section{Results}

\section{Preparation of hlgG1-Fc-9Arg protein}

To develop a delivery system, we performed a PCR-modification of the hIgG1-Fc plasmid with nine-arginine sequences (9Arg-GGGs-9Arg) to produce a hIgG1-Fc-9Arg expression plasmid. Agarose gel electrophoresis indicated an amplified band with the size of approximately 850 bp originating from 9Arg sequences in the hIgG1-Fc-9Arg expression plasmid (Additional file 1). DNA sequencing further validated successful construction of the hIgG1-Fc-9Arg expression plasmid (Additional file 1). With this plasmid, Expi293F cells were transiently transfected to produce hIgG1-Fc-9Arg protein. Protein analysis revealed a successful generation of approximately $10 \mathrm{~g} / \mathrm{L}$ fusion $\mathrm{Fc}$ protein. Additionally, the SDS-PAGE analysis of hIgG1-Fc-9Arg protein showed two separated bands with either $30 \mathrm{kDa}$ or $35 \mathrm{kDa}$ Additional file 1). Interestingly, native PAGE under nonreducing conditions revealed a $70 \mathrm{kDa}$ single band (Additional file 1).

\section{Characterization of hlgG1-Fc-9Arg/pDNA complex}

hIgG1-Fc-9Arg protein produced complexes with pDNA in various ratios by electrostatic interactions of positively charged hIgG1-Fc-9Arg protein with pDNA. (Additional file 2). Agarose gel electrophoresis showed a complexation of the protein with plasmid DNA (pDNA) by showing retardation of pDNA bands at the ratio from 20/1 up to 200/1 (Fig. 1a). Atomic force microscopy (AFM) exhibited surface properties of the complex of ratios of 20/1, 50/1, and 100/1 prepared in $\mathrm{ddH}_{2} \mathrm{O}$ of pH 7.0 (Fig. 1b (1)-(5)). Among these complexes, the $50 / 1$ complex had a coiled DNA structure (Fig. 1b (3)-(4), suggesting a structure of the complex combined with proteins. Further analysis of the complex using FE-TEM revealed that the complex had a globular structure of nanometer size (Fig. 1c and d).
$\mathrm{pH}$ and serum stability of hlgG1-Fc-9Arg/pDNA complex The measurement of $\mathrm{pH}$ effects on hIgG1-Fc-9Arg protein showed that the protein was stable under the range of $\mathrm{pH}$ values, mimicking gastrointestinal $\mathrm{pH}$-fluctuations (Fig. 2a). The complex (50:1, pDNA: hIgG1-Fc-9Arg ( $w /$ w)) revealed maintenance of a complex structure over $6 \mathrm{~h}$ under stomach $\mathrm{pH}$ conditions $(\sim \mathrm{pH} 2)$ without exposing the pDNA (Fig. $2 \mathrm{~b}$ ). The release of intact pDNA from the complex after SDS treatment further confirmed good protection of pDNA in the complex under acidic conditions (Fig. 2b).

The serum effects of the various ratios of the complex indicated that the complex maintained its stability with minimal release of pDNA under the 10\% FBS condition for $24 \mathrm{~h}$ (Fig. 2c). However, the complex under FBS conditions released more pDNA as the complex had a higher pDNA ratio due to surpassing the complexation ability of the protein with pDNA.

\section{FcRn-mediated cellular uptake of hlgG1-Fc-9Arg/pDNA complex}

Fc ligands in the hIgG1-Fc-9Arg/pDNA complex facilitate the binding of the complex to target cells that express FcRn receptors (Fig. 3a). The addition of FITC-hIgG1-Fc-9Arg complexes to Caco-2 and HEK 293 cells showed green fluorescent signals emitted from the FITC in the complexes (Fig. 3b). There was no FITC signal in the FcRn receptor-negative HeLa cells, indicating that the FITC signal came from the cellular uptake of the complex [23, 35]. Furthermore, stronger FITC signals from Caco- 2 cells than from HEK 293 cells suggested that cellular uptake of the complex correlated with the level of $\mathrm{FcRn}$ receptor expression on the cell surface (Fig. $3 \mathrm{~b}$ ).

The treatment of a complex consisting of hIgG1-Fc-Arg with various ratios of pDNA (pGFP) led to the expression of GFP plasmid in Caco-2 cells (Fig. 3c). The over 50/1 ratio- complex showed better GFP expression than did the 20/1 ratio complex in the cells. The results suggested FcRn-mediated cellular uptake of the complex.

\section{Cellular toxicity of hlgG1-Fc-9Arg/pDNA complex}

The MTT-based assay in Caco-2 cells was performed to evaluate the potential cellular toxicity of both hIgG1-Fc-9Arg protein and its complex with pDNA. As a delivery vehicle of pDNA, hIgG1-Fc-9Arg protein showed almost $100 \%$ Caco- 2 cell viability with the treatment of $3.75 \mu \mathrm{g}$, while bPEI maintained only $50 \%$ cell viability (Fig. 4a). At the comparisons of the cell viability with a high amount of delivery vehicles, hIgG1-Fc-9Arg demonstrated relatively minimal toxicity comparable with that of the nontoxicity of lipofectamine treatment in the cells (Fig. 4a). These experimental results suggested that hIgG1-Fc-9Arg protein is a safe delivery vehicle for pDNA to the cells. 


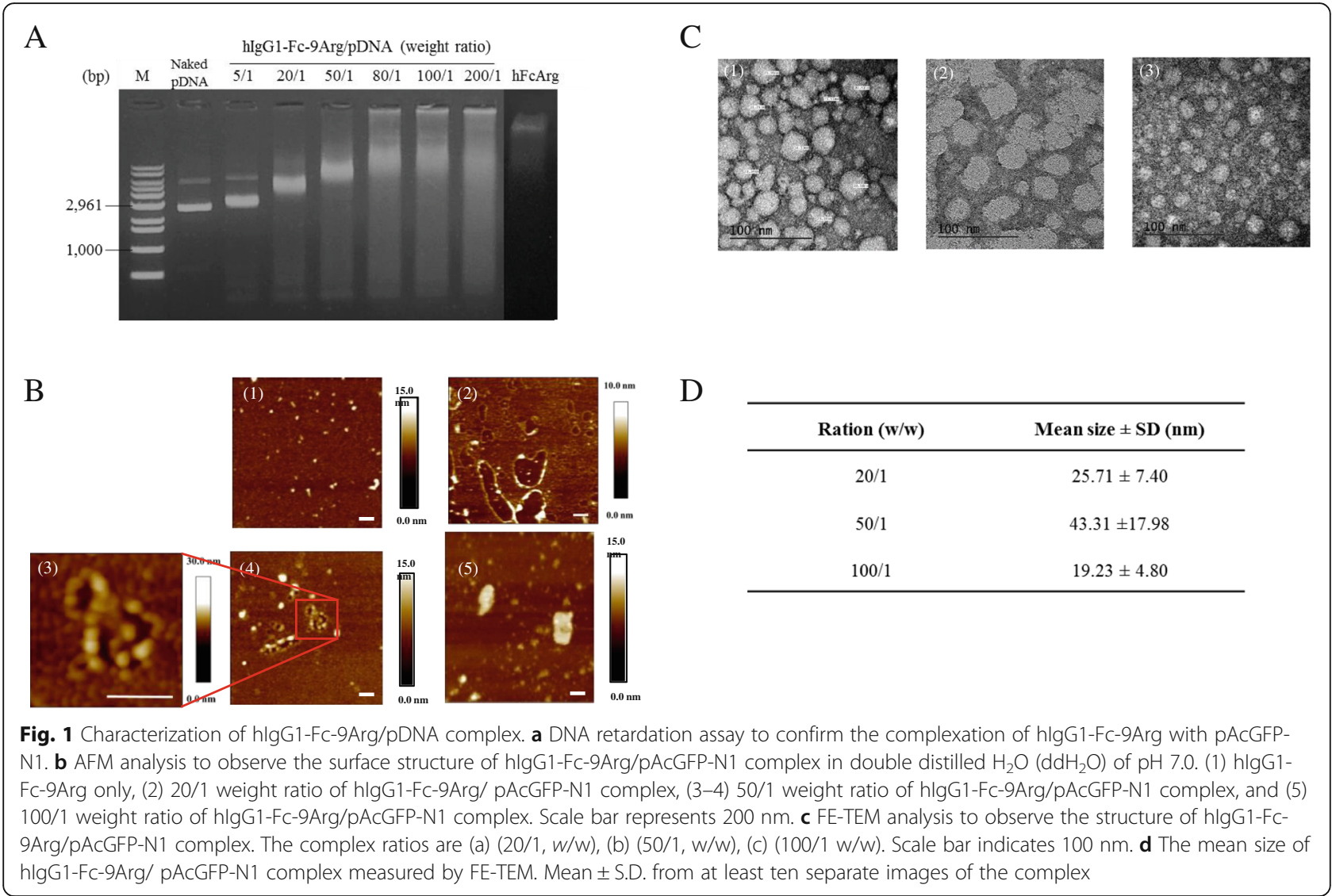

The hIgG1-Fc-9Arg/pDNA complex $(50 / 1, w / w)$ was safe for the survival of Caco-2 cells compared to the significant toxicity of the bPEI/pDNA complexes (Fig. 4b). Interestingly, the complex containing $0.5 \mu \mathrm{g}$ pDNA, which is five times more amount than that of the complex containing $0.1 \mu \mathrm{g}$ demonstrated the cellular safety of the complex similar to that of lipofectamine/pDNA complexes in Caco-2 cells (Fig. 4b).

\section{Cellular transport of hlgG1-Fc-9Arg complex across the Caco-2 cell monolayer}

Materials absorbed on the small intestine move from the apical to the basolateral region. Due to the formation of the monolayer-polarized structure, the Caco-2 cell line is a suitable experimental model for simulation of cellular transport of materials (Fig. 5a Top) [33]. The simulation of cellular transport of various ratios of hIgG1-Fc-9Arg complexes showed approximately 2 to 3 times more cellular transport in 50/1 and 100/1 complexes compared to that of naked pDNA, a negative experimental control (Fig. 5a Bottom).

Confocal microscopy analysis indicated movement of the complex from apical to basolateral regions, suggesting that the 50/1 ratio of the complex produced visible fluorescent images (Fig. 5b). Moreover, FITC-hIgG1-Fc-9Arg did not overlap with the late endosomes that were stained with lysotracker. However, the observation of the FITC signal in the endosomal complex at $4 \mathrm{~h}$ suggested the translocation of FITC-hIgG1-Fc-9Arg complex from the cell surface to the intracellular space through endosomal cycling (Additional file 3). Similarly, the addition of bobo-3 iodide-hIgG1-Fc-9Arg complex to Caco-2 cells showed strong red fluorescence signals in the cells. The $50 / 1$ ratio of the complex had the best fluorescent signal compared to other ratios of the complex at intestinal $\mathrm{pH}$ ( $\mathrm{pH}$ 6.0) (Additional file 3). These observations further confirmed the intracellular movement and expression of the pDNA combined with hIgG1-Fc-9Arg.

\section{Biodistribution and antidiabetic effect of a hIGg1-Fc-9Arg complex}

Oral administration of the FITC-hIgG1-Fc-9Arg complex $(1: 50$ ratio, $w / w)$ to the mouse indicated explicit organ distribution of the complex by emitting fluorescence signals at either 1 or 3 h' post-administration (Fig. 6a). Fluorescence signals from the primary organ and GI tract in Balb/c mice demonstrated evidence of signals mostly from the major organs, including liver and kidney, as well as some parts of the GI tract, including the small intestine (Fig. 6a). Quantification of the fluorescence signals indicated 


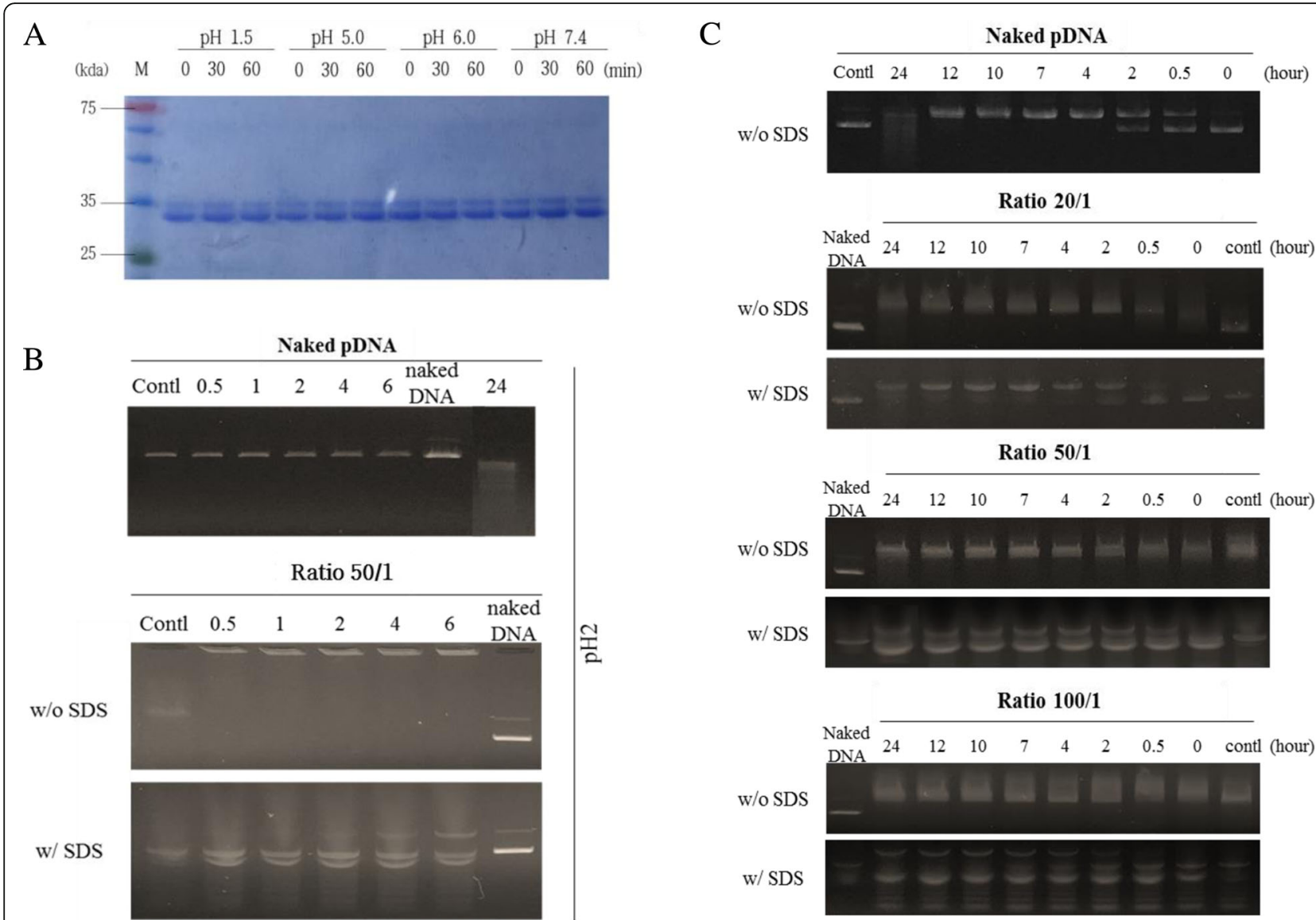

Fig. 2 pH and serum stability of hlgG1-Fc-9Arg/pAcGFP-N1 complex. a Stability of the hlgG1-Fc-9Arg protein at various pH conditions (pH 1.5, 5.0, 6.0 and 7.4). b Stability of pDNA at 50/1 ratio of hlgG1-Fc-9Arg/pDNA complexes in the stomach environment (pH 2.0). c Serum stability of the complex. Naked pDNA and various ratios of hlgG1-Fc-9Arg/pDNA complexes were treated with 10\% fetal bovine serum (FBS) at various time intervals (0, 0.5, 2, $4,7,10,12,24 \mathrm{~h}$ ). Complexes were released by adding $1 \%$ SDS to determine the damage of pDNA. Representative images from at least three results

stronger signals from liver and kidney than from other organs (Fig. 6b). Interestingly, detectable signals from the GI tract including stomach, small intestine, and colon suggested the ubiquitous distribution of FcRn receptors in the GI tract with emphasis on slightly more distribution in the upper parts of the small intestine and colon (Fig. 6c).

In the in vivo study, leptin receptor-deficient mice treated with the GLP-1 gene developed mild hyperglycemia for eight weeks. The plasma levels of active GLP-1 in the hIgG1-Fc-9Arg/p $\beta$-sp-GLP1 group increased nearly five-fold compared with the control groups in $\mathrm{db} / \mathrm{db}$ mice (Additional file 4). However, serum insulin levels, blood glucose levels, and body weights were not significantly different but only slightly increased or decreased between control and oral administration mouse models (Additional file 4). In addition, $H \& E$ histology of the jejunum revealed negligible cellular toxicity and inflammation from oral administration of hIgG1-Fc-9Arg and gene complexes (Additional file 4).

\section{Discussion}

Glucagon-like peptide-1 (GLP-1) is an antidiabetic hormone released from intestinal $\mathrm{L}$ cells into the circulation system. GLP-1 prevents type 2 diabetes mellitus (T2DM) patients from hyperglycemic episodes [20]. However, short biological half-life ( $<5 \mathrm{~min}$ ) and rapid clearance of GLP-1 often limit its therapeutic usefulness. Here, we developed a GLP-1 gene delivery system to achieve the extended antidiabetic effect by delivery of a GLP-1 expression plasmid (Additional file 5). The GLP-1 gene delivery system was a nano-complex consisting of GLP-1 expression plasmid and its delivery vehicle, a positively modified Fc fragment (hIgG1-Fc-Arg) having targeting ability for FcRn receptor located on intestinal L cells [24].

Design of the delivery vehicle is based on the utilization of interaction between hIgG1-Fc and FcRn receptor on intestinal L cells, which are predominantly located in the ileum and colon as open-type epithelial cells directly interacting with nutrients in the intestinal lumen [6]. In addition, hIgG isotypes had better affinities (i.e., lower $\mathrm{K}_{\mathrm{D}}$ ) for $\mathrm{mFcRn}$ than did hFcRn [36]. For the delivery of 

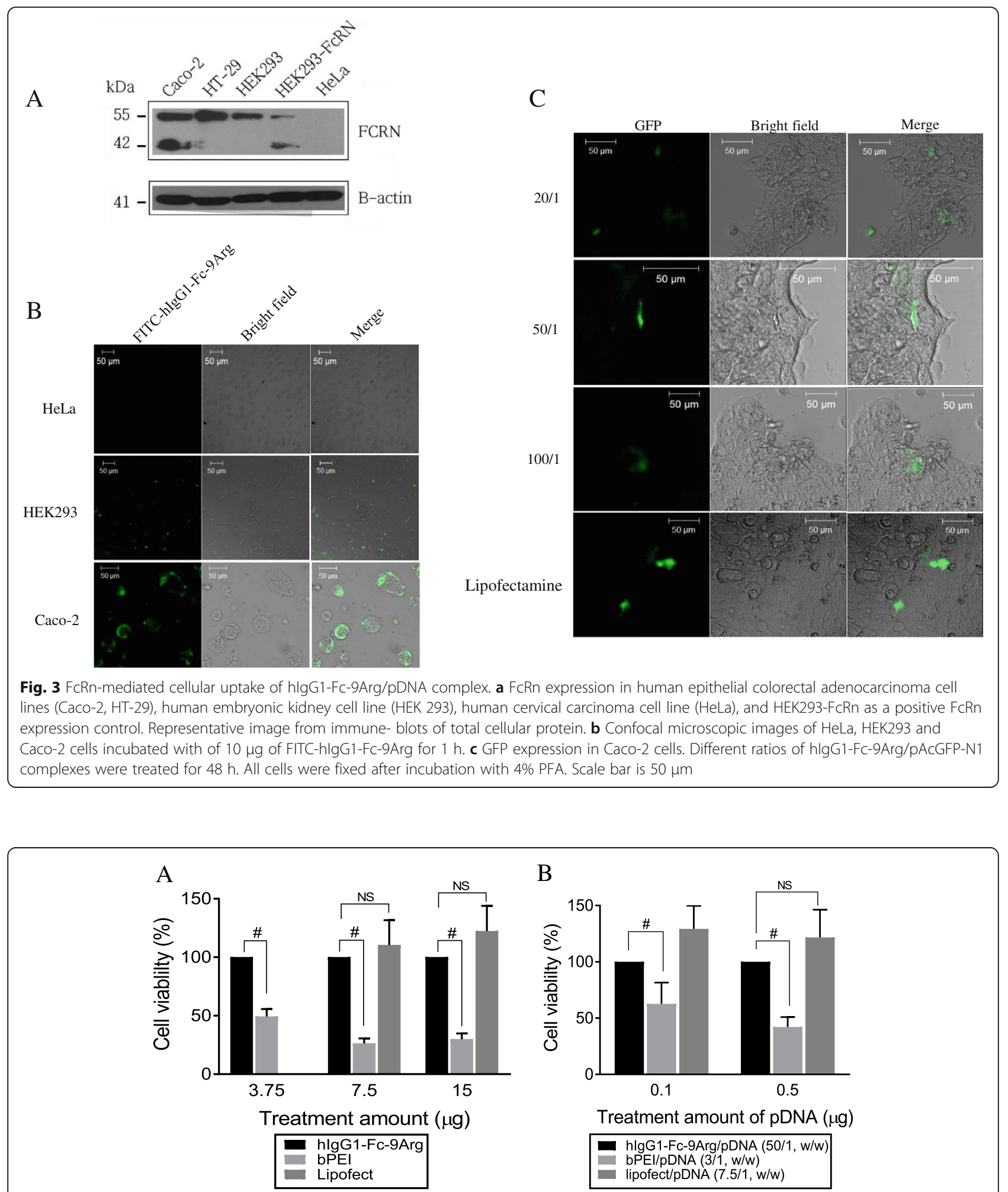

Fig. 4 Relative cellular toxicity of hlgG1-Fc-9Arg/pDNA complexes. Caco-2 cells were incubated with hlgG1-Fc-9Arg/pDNA for 24 h. a MTT assay to estimate the cellular toxicity of hlgG1-Fc-9Arg protein to Caco-2 cells as a delivery vehicle. Mean \pm SD $(n=5)$, 2-way ANOVA with Bonferroni's multiple comparisons test. \# was $P<0.05$. b The estimation of the relative cellular toxicity of hlgG1-Fc-9Arg/pDNA complex evaluated by MTT assay. Relative cell viability indicated cellular toxicity of the complex. Relative cell viability obtained from the treatment with hlgG1-Fc-9Arg/pDNA complex was compared with that of cationic polymers (bPEl and lipofectamine). Mean \pm SD $(n=5)$, 2-way ANOVA with Tukey's multiple comparisons test. \# was $P<0.05$ 


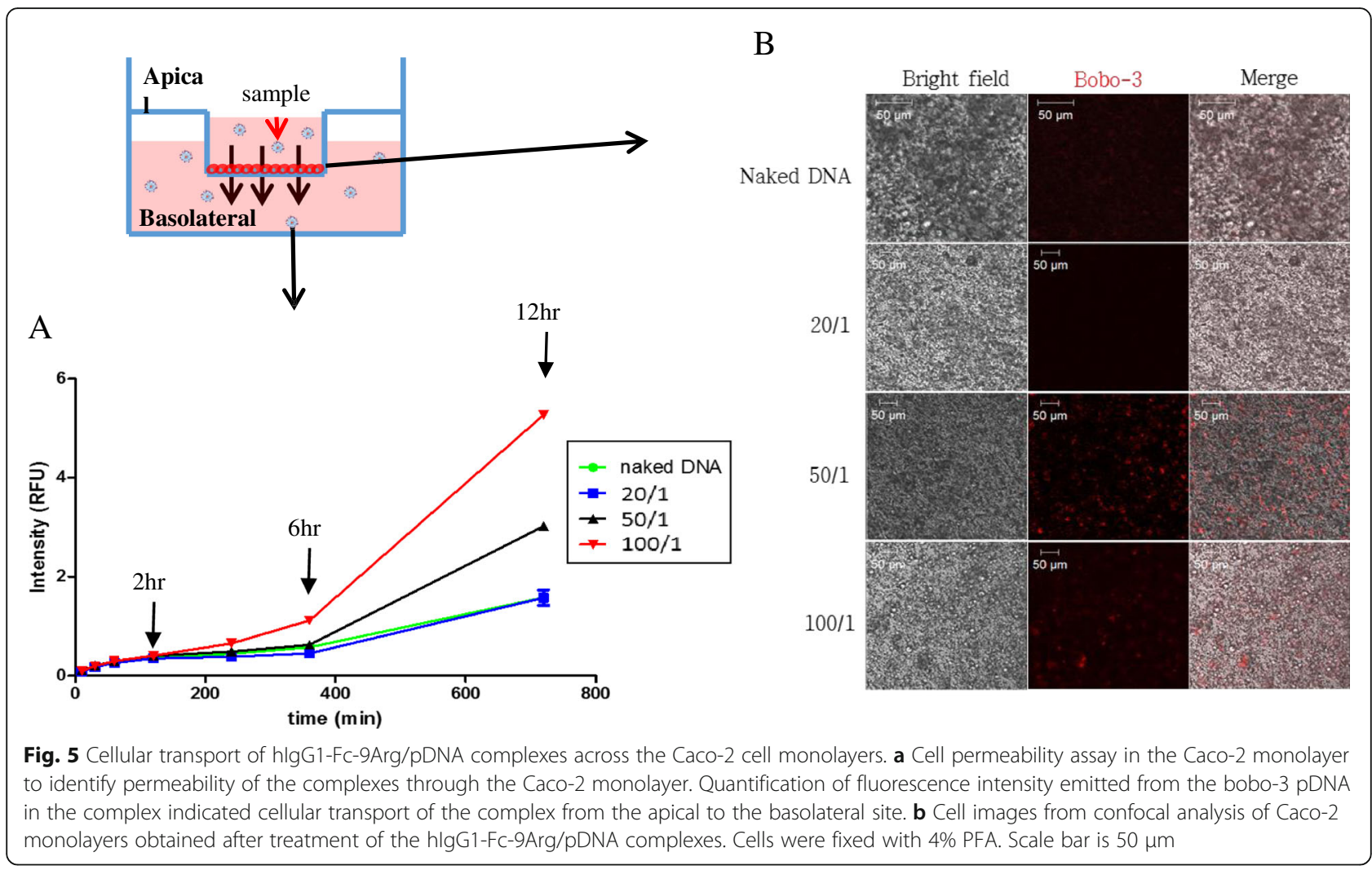

negatively charged plasmids, modification of hIgG1-Fc was performed by adding nine arginine sequences to confer positive charges to hIgG1-Fc [35-37]. During the confirmation of a protein structure of hIgG1-Fc-Arg, which was produced from in vitro translation, native PAGE revealed a single band under nonreducing condition while two separated bands were observed in SDS-PAGE under reducing condition. These results imply that a bivalent antibody-like structure of hIgG1-Fc has not affected by the extension of 9 Arg through the genetic modification process. From the complexation of hIgG1-Fc-Arg with pDNA, we could detect size information from the FE-TEM analysis. However, we could not detect particle size or surface charge with conventional analytical tools such as dynamic light scattering (DLS) or zeta potential (ZP). We believe that the structural instability from the weak electrostatic interaction between pDNA and protein, including only 9 Arg positive charges, could limit the robust application of the DLS and ZP to measure both size and charge of the complexes [38-41].

For the development of an oral delivery system with nanocarriers through electrostatic interaction, the effect of fluctuations in $\mathrm{pH}$ during gastrointestinal transit and serum in the systemic circulation should be considered as biochemical barriers [39, 40]. Our simulated results under the physiological condition of $\mathrm{pH}$ fluctuations and serum concentration indicated that complex having over 50/1 ratio did not lose its stability and provided protection of its pDNA. Considering isoelectric point (pI) of 10.8 in arginine, we believe intestinal $\mathrm{pH}$ changes ranged from $\mathrm{pH} 2$ to 8 did not change electrical charges in hIgG1-Fc-Arg, therefore; electrostatic complexation with pDNA seemed to maintain the complex under $\mathrm{pH}$ fluctuations.

The cellular uptake of the complex under a simulated intestinal condition presented with the polarized-monolayer Caco-2 cell system [25, 33] demonstrated uptake of the complex through an interaction between Fc ligand and FcRn receptor existed on the surface of Caco- 2 cell membrane [23, 35]. Furthermore, cellular transportation of the complex suggested that the complex could have the dual function of both facilitation of cellular uptake and cellular transportation. Beside these abilities of the complex, we could confirm that the complex has minimal cellular toxicity comparable with nontoxicity of a commercial transfection reagent. Considering oral administration of the hIgG1-Fc-9Arg/pDNA complexes, we could insist safety of current nano-complex over other cation based-complex systems [38, 42].

The biodistribution of the nano-complex in an animal model demonstrated detectable distributions in the most parts of major organs and gastrointestinal tract. The gradual increase of biodistribution of the complex in the ileum and colon over time is also matched with the previous report about the predominant distribution of FcRn receptors 


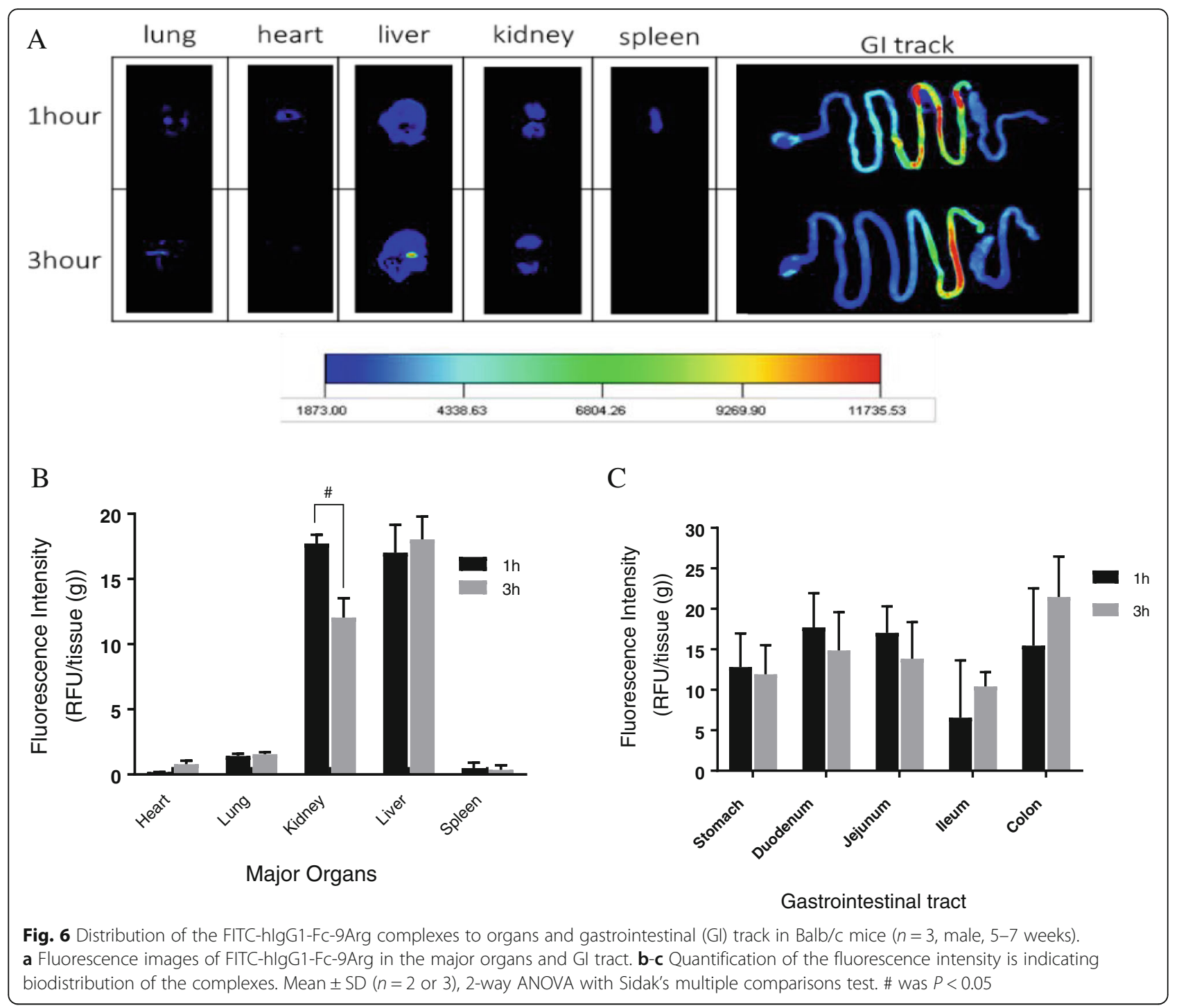

on the surface of ileum and colon [6]. An in vivo type 2 diabetes treatment study showed the enhancement of serum GLP-1 from oral administration of a hIgG1-Fc-9Arg/pGLP-1 complex to the leptin-receptor deficient mouse $\left(\mathrm{Lep}_{\mathrm{db} / \mathrm{db}}\right)$. However, body weight and blood glucose level seemed to show marginal changes. We assume that extreme hyperglycemic condition reaching to $600 \mathrm{mg} / \mathrm{dl}$ of blood glucose level in lep $\mathrm{db}_{\mathrm{db}}$ mouse compared to an average of $\sim 200 \mathrm{mg} / \mathrm{dl}$ of that in human T2DM patients led to masking the noticeable regulatory effect of GLP-1 [43, 44]. With this limitation of the current study, we believe that efficacy of the current nano-complex containing GLP-1 can be warranted in using better diabetic mouse model having the similar hyperglycemic condition to human T2DM. Lastly, it is noteworthy to mention the nano-complex did not show intestinal toxicity, especially jejunal tissue known as FcRn rich cells targeted by current hIgG1-Fc-9Arg/pDNA complex system.

\section{Conclusion}

In conclusion, we have demonstrated that oral gene delivery with a hIgG1-Fc-9Arg gene carrier targeted FcRn receptor and facilitated transepithelial transport of the gene complex. Oral delivery of $\mathrm{p} \beta$-sp-GLP-1 gene with hIgG1-Fc-9Arg in type 2 diabetic animal model revealed stimulation of GLP-1 expression, suggesting a promising approach for the treatment of type 2 diabetes.

\section{Additional files}

Additional file 1: Preparation of hlgG1-Fc-9Arg. A. C-terminal 9Arg extension of human IgG1-Fc by PCR. Lane 1. hlgG1-Fc-9Arg PCR (annealing Tm:55, 850 bp), Mw. DNA ladder, lane 2. hlgG1-Fc-9Arg PCR (annealing Tm:52, 850 bp). Template for PCR was an Avastin heavy chain. B. DNA sequence analysis of hlgG1-Fc-9Arg expression vector. C. SDS-PAGE with reduced hlgG1-Fc-9Arg. Mw. protein ladder (10-245 kDa), lane1. 0.1 Mg, lane 2. one $\mu \mathrm{g}$, land 3. ten $\mu \mathrm{g}$ and PAGE with non-reduced hlgG1-Fc-9Arg (lane 1) and Mw (protein ladder (10-245 kDa)). (PPTX 314 kb) 
Additional file 2: Complexation of hlgG1-Fc-9Arg with pAcGFP-N1. (PPTX $36 \mathrm{~kb}$ )

Additional file 3: Endosomal trafficking of hlgG1-Fc-9Arg complex A. Cellular uptake and endosomal escape of FITC-hlgG1-Fc-9Arg in Caco-2 cells. B. Determination of bobo-3-pDNA complexed with hlgG1-Fc-9Arg on 50/1 weight ratio for tracking complexes mediated FcRn and evaluation of presence pDNA in Caco-2 cells. Lipofectamine used as positive control. Scale bar is $50 \mu \mathrm{m}$. (PPTX $1263 \mathrm{~kb}$ )

Additional file 4: Anti-diabetic effect and tissue toxicity of the complex. A Anti-diabetic effect of orally administered hlgG1-Fc-9Arg/pGLP-1 complex (20/1) and H\&E histology analysis in balb/c mice $(n=3$, male,

$5-7$ weeks) as a normal mouse and lep $\mathrm{pdb}_{\mathrm{db}}$ mice ( $n=4$, male, seven weeks) as a $\mathrm{db} / \mathrm{db}$ mouse. (a) Serum insulin concentration, (b) serum GLP-1 concentration, (c) body weight, (d) blood glucose level at day 44 after continuous oral administration of the complex and its comparison of with the blood glucose level before administration of the complex (day 0). B H\&E histology analysis of jejunum tissue from the small intestine after oral administration of the complex. (PPTX $1853 \mathrm{~kb}$ )

Additional file 5: The strategy of the intestinal receptor-mediated delivery of therapeutic gene. (PPTX 547 kb)

\section{Funding}

This research was supported by The Leading Human Resource Training Program of Regional Neo industry through the National Research Foundation of Korea(NRF) funded by the Ministry of Science, ICT and Future Planning(NRF-2016H1D5A1910188, NRF-2015R1D1A1A09060567) and this work was partly supported by the technology development program of MSS (S2498967) and the ICT development R\&D program of MSIT (S2498967).

\section{Availability of data and materials}

The datasets generated and analyzed in the current study are available from the corresponding authors on request.

\section{Authors' contributions}

SCha and SL designed and performed experiments and analyzed data. SHK and $\mathrm{MNH}$ helped with data interpretation. YJK, SC, and YKL extensively contributed to either research guidance or the manuscript preparation. All authors read and approved the final manuscript.

\section{Ethics approval and consent to participate}

Not applicable.

\section{Consent for publication}

Not applicable.

\section{Competing interests}

The authors declare that they have no competing interersts.

\section{Publisher's Note}

Springer Nature remains neutral with regard to jurisdictional claims in published maps and institutional affiliations.

\section{Author details}

'Department of Biomedical Chemistry, Konkuk University, Chungju 27478, Republic of Korea. ${ }^{2}$ KB-Biomed, Chungju 27469, Republic of Korea. ${ }^{3}$ Department of Chemical and Biological Engineering, Korea National University of Transportation, Chungju 27469, Republic of Korea. ${ }^{4} 4 \mathrm{D}$ Biomaterials Center, Korea National University of Transportation, Jeungpyeong 27909, Republic of Korea.

\section{Received: 21 May 2018 Accepted: 27 June 2018}

\section{Published online: 27 July 2018}

\section{References}

1. Global report on diabetes. World Health Organization; 2016.

2. Alberti KG, Zimmet PZ. Definition, diagnosis and classification of diabetes mellitus and its complications. Part 1: diagnosis and classification of diabetes mellitus provisional report of a WHO consultation. Diabet Med. 1998;15:539-53.
3. American Diabetes A. Diagnosis and classification of diabetes mellitus. Diabetes Care. 2004;27(Suppl 1):S5-S10.

4. Yechoor V, Chan L. Gene therapy progress and prospects: gene therapy for diabetes mellitus. Gene Ther. 2005;12:101-7.

5. Wong SL, Priestman A, Holmes DT. Recurrent hypoglycemia from insulin autoimmune syndrome. J Gen Intern Med. 2014;29:250-4.

6. Eissele R, Goke R, Willemer S, Harthus HP, Vermeer H, Arnold R, Goke B. Glucagon-like peptide-1 cells in the gastrointestinal tract and pancreas of rat, pig and man. Eur J Clin Investig. 1992;22:283-91.

7. Choi S, Oh S, Lee M, Kim SW. Glucagon-like peptide-1 plasmid construction and delivery for the treatment of type 2 diabetes. Mol Ther. 2005;12:885-91.

8. Dan M, Chantler JK. A novel pancreatropic coxsackievirus vector expressing glucagon-like peptide 1 reduces hyperglycemia in streptozotocin-treated mice. J Virol. 2011;85:12759-68.

9. Holst JJ. The physiology of glucagon-like peptide 1. Physiol Rev. 2007;87: 1409-39.

10. Moon MJ, Park S, Kim DK, Cho EB, Hwang JI, Vaudry H, Seong JY. Structural and molecular conservation of glucagon-like Peptide-1 and its receptor confers selective ligand-receptor interaction. Front Endocrinol (Lausanne). 2012;3:141.

11. Oh S, Lee M, Ko KS, Choi S, Kim SW. GLP-1 gene delivery for the treatment of type 2 diabetes. Mol Ther. 2003;7:478-83.

12. Petersen $N$, Reimann F, Bartfeld S, Farin HF, Ringnalda FC, Vries RG, van den Brink S, Clevers H, Gribble FM, de Koning EJ. Generation of L cells in mouse and human small intestine organoids. Diabetes. 2014;63:410-20.

13. Yang $Y$, Chen F, Wan D, Liu Y, Yang L, Feng H, Cui X, Gao X, Song $H$. Expression and characterization of a potent long-acting GLP-1 receptor agonist, GLP-1-IgG2sigma-fc. PLoS One. 2016;11:e0156449.

14. Bakker JM, Bleeker WK, Parren PW. Therapeutic antibody gene transfer: an active approach to passive immunity. Mol Ther. 2004;10:411-6.

15. Ewe A, Przybylski S, Burkhardt J, Janke A, Appelhans D, Aigner A. A novel tyrosine-modified low molecular weight polyethylenimine (P10Y) for efficient siRNA delivery in vitro and in vivo. J Control Release. 2016;230:13-25.

16. Kumar SR, Markusic DM, Biswas M, High KA, Herzog RW. Clinical development of gene therapy: results and lessons from recent successes. Mol Ther Methods Clin Dev. 2016;3:16034.

17. Liu JW, Cheng J. Molecular mechanism of immune response induced by foreign plasmid DNA after oral administration in mice. World J Gastroenterol. 2007;13:3847-54.

18. Morille M, Passirani C, Vonarbourg A, Clavreul A, Benoit JP. Progress in developing cationic vectors for non-viral systemic gene therapy against cancer. Biomaterials. 2008;29:3477-96.

19. Naldini L. Gene therapy returns to Centre stage. Nature. 2015;526:351-60.

20. Yi SW, Yune TY, Kim TW, Chung H, Choi YW, Kwon IC, Lee EB, Jeong SY. A cationic lipid emulsion/DNA complex as a physically stable and serumresistant gene delivery system. Pharm Res. 2000;17:314-20.

21. Loretz B, Foger F, Werle M, Bernkop-Schnurch A. Oral gene delivery: strategies to improve stability of pDNA towards intestinal digestion. J Drug Target. 2006;14:311-9.

22. Araujo F, Fonte P, Santos HA, Sarmento B. Oral delivery of glucagon-like peptide-1 and analogs: alternatives for diabetes control? J Diabetes Sci Technol. 2012;6:1486-97.

23. Dickinson BL, Badizadegan K, Wu Z, Ahouse JC, Zhu X, Simister NE, Blumberg RS, Lencer WI. Bidirectional FcRn-dependent IgG transport in a polarized human intestinal epithelial cell line. J Clin Invest. 1999;104:903-11.

24. Roopenian DC, Akilesh S. FcRn: the neonatal fc receptor comes of age. Nat Rev Immunol. 2007:7:715-25.

25. Sand KM, Bern M, Nilsen J, Noordzij HT, Sandlie I, Andersen JT. Unraveling the interaction between FcRn and albumin: opportunities for Design of Albumin-Based Therapeutics. Front Immunol. 2014;5:682.

26. Petkova SB, Akilesh S, Sproule TJ, Christianson GJ, Al Khabbaz H, Brown AC, Presta LG, Meng YG, Roopenian DC. Enhanced half-life of genetically engineered human IgG1 antibodies in a humanized FCRn mouse model: potential application in humorally mediated autoimmune disease. Int Immunol. 2006;18:1759-69.

27. Souders CA, Nelson SC, Wang Y, Crowley AR, Klempner MS, Thomas W Jr. A novel in vitro assay to predict neonatal fc receptor-mediated human lgG half-life. MAbs. 2015;7:912-21.

28. Alhakamy NA, Berkland CJ. Polyarginine molecular weight determines transfection efficiency of calcium condensed complexes. Mol Pharm. 2013; 10:1940-8. 
29. Unverdorben F, Richter F, Hutt M, Seifert O, Malinge P, Fischer N, Kontermann RE. Pharmacokinetic properties of lgG and various fc fusion proteins in mice. MAbs. 2016;8:120-8.

30. Vaccaro C, Zhou J, Ober RJ, Ward ES. Engineering the fc region of immunoglobulin $\mathrm{G}$ to modulate in vivo antibody levels. Nat Biotechnol. 2005;23:1283-8

31. Wang Q, Chen K, Liu R, Zhao F, Gupta S, Zhang N, Prud'homme GJ. Novel GLP-1 fusion chimera as potent long acting GLP-1 receptor agonist. PLoS One. 2010:5:e12734.

32. Haley J, Kabiru P, Geng Y. Effect of clustered peptide binding on DNA condensation. Mol BioSyst. 2010;6:249-55.

33. Hubatsch I, Ragnarsson EG, Artursson P. Determination of drug permeability and prediction of drug absorption in Caco-2 monolayers. Nat Protoc. 2007; 2:2111-9.

34. Kauffman AL, Gyurdieva AV, Mabus JR, Ferguson C, Yan Z, Hornby PJ. Alternative functional in vitro models of human intestinal epithelia. Front Pharmacol. 2013;4:79.

35. Li Z, Palaniyandi S, Zeng R, Tuo W, Roopenian DC, Zhu X. Transfer of IgG in the female genital tract by MHC class I-related neonatal fc receptor ( $F C R n)$ confers protective immunity to vaginal infection. Proc Natl Acad Sci U S A. 2011;108:4388-93.

36. Neuber T, Frese K, Jaehrling J, Jager S, Daubert D, Felderer K, Linnemann M, Hohne A, Kaden S, Kolln J, et al. Characterization and screening of IgG binding to the neonatal fc receptor. MAbs. 2014;6:928-42.

37. Jorgensen ML, Friis NA, Just J, Madsen P, Petersen SV, Kristensen P. Expression of single-chain variable fragments fused with the fc-region of rabbit lgG in Leishmania tarentolae. Microb Cell Factories. 2014;13:9.

38. Kircheis R, Schuller S, Brunner S, Ogris M, Heider KH, Zauner W, Wagner E. Polycation-based DNA complexes for tumor-targeted gene delivery in vivo. J Gene Med. 1999;1:111-20.

39. Martz L. Oral nanoparticles. SciBX. 2013;6:1

40. Khatun Z, Nurunnabi M, Reeck GR, Cho KJ, Lee YK. Oral delivery of taurocholic acid linked heparin-docetaxel conjugates for cancer therapy. J Control Release. 2013;170:74-82.

41. Motta SBP, Del Favero E, Rondelli V, Cantù L, Amici A, Pozzi D, Caracciolo G. Nanoscale structure of protamine/DNA complexes for gene delivery. Appl Phys Lett. 2013:102:053703.

42. Furgeson DY, Yockman JW, Janat MM, Kim SW. Tumor efficacy and biodistribution of linear polyethylenimine-cholesterol/DNA complexes. Mol Ther. 2004;9:837-45.

43. Gaddy DF, Riedel MJ, Pejawar-Gaddy S, Kieffer TJ, Robbins PD. In vivo expression of HGF/NK1 and GLP-1 from dsAAV vectors enhances pancreatic ss-cell proliferation and improves pathology in the $\mathrm{db} / \mathrm{db}$ mouse model of diabetes. Diabetes. 2010;59:3108-16.

44. Wang B, Chandrasekera PC, Pippin JJ. Leptin- and leptin receptor-deficient rodent models: relevance for human type 2 diabetes. Curr Diabetes Rev. 2014;10:131-45.

\section{Ready to submit your research? Choose BMC and benefit from:}

- fast, convenient online submission

- thorough peer review by experienced researchers in your field

- rapid publication on acceptance

- support for research data, including large and complex data types

- gold Open Access which fosters wider collaboration and increased citations

- maximum visibility for your research: over $100 \mathrm{M}$ website views per year

At BMC, research is always in progress.

Learn more biomedcentral.com/submissions 